\title{
Polar Lipids and Glycine Betaine from Haloalkaliphilic Archaebacteria
}

\author{
By M. DE ROSA, ${ }^{1}$ A. GAMBACORTA,${ }^{2 *}$ W. D. GRANT,${ }^{3}$ V. LANZOTTI ${ }^{2}$ \\ AND B. NICOLAUS ${ }^{2}$ \\ ${ }^{1}$ Dipartimento di Biochimica delle Macromolecole, Universita' di Napoli, Napoli, Italy \\ ${ }^{2}$ Istituto per la Chimica di Molecole di Interesse Biologico del Consiglio Nazionale delle Ricerche, \\ 80072-Arco Felice, via Toiano 6, Napoli, Italy \\ ${ }^{3}$ Department of Microbiology, University of Leicester, Leicester LEI 7RH, UK
}

(Received 5 May 1987; revised 20 July 1987)

\begin{abstract}
The major polar lipids from haloalkaliphilic archaebacteria of the genera Natronobacterium and Natronococcus have been analysed by spectroscopic methods, including ${ }^{13} \mathrm{C} \mathrm{NMR}$, to establish unequivocal structural detail. Diether forms of phosphatidylglycerol (PG) and phosphatidylglycerophosphate (PGP) are the major polar lipids; PGP is the main component for all species. Natronobacterium spp. show a preponderance of the 2-O-sesterterpanyl-3-O-phytanyl glycerol diether form $\left(\mathrm{C}_{25}, \mathrm{C}_{20}\right)$ of both PG and PGP, whereas Natronococcus occultus has a preponderance of the diphytanylglycerol diether form $\left(\mathrm{C}_{20}, \mathrm{C}_{20}\right)$ for both. In all cases, PGP $\left(\mathrm{C}_{25}, \mathrm{C}_{20}\right.$ and $\mathrm{C}_{20}, \mathrm{C}_{20}$ forms) eluted from silica columns in association with glycine betaine (trimethylglycine).
\end{abstract}

\section{INTRODUCTION}

All archaebacteria isolated to date have lipids based on isopranyl glycerol ethers rather than the usual fatty acid glycerol esters (Langworthy, 1985; De Rosa \& Gambacorta, 1986). The halophilic archaebacteria comprise two main groups: those isolates that grow at neutrality or close to neutrality, and those isolates that grow only at high $\mathrm{pH}$ (the haloalkaliphiles). All halophilic archaebacteria have lipids based on the archaebacterial core lipid 2,3-di- $O$-phytanyl$s n$-glycerol $\left(C_{20}, C_{20}\right)$ (Kates, 1978), and certain isolates, notably the haloalkaliphiles, possess substantial amounts of 2-O-sesterterpanyl-3-O-phytanyl-sn-glycerol $\left(\mathrm{C}_{25}, \mathrm{C}_{20}\right)$ (De Rosa et al., 1982, 1983). The complex lipids of these archaebacteria have free glycerol hydroxyl groups linked to different polar groups, giving rise to a wide range of different structures that have proved useful in the taxonomy of the group (Kates, 1986; Ross et al., 1985; Langworthy \& Pond, 1986; Ross \& Grant, 1985; Torreblanca et al., 1986).

The haloalkaliphilic archaebacteria of the genera Natronobacterium and Natronococcus have a relatively simple polar lipid composition, lacking glycolipids and amino lipids. The main polar lipids are thought to be the $\mathrm{C}_{20}, \mathrm{C}_{20}$ and $\mathrm{C}_{25}, \mathrm{C}_{20}$ forms of phosphatidylglycerol (PG) and phosphatidylglycerophosphate (PGP), although there are small amounts of two or three unidentified phospholipids (Ross et al., 1985; Ross \& Grant, 1985; Tindall et al., 1984). Natronococcus and Natronobacterium spp., despite being clearly distinct from each other by DNA-DNA and DNA-16S rRNA hybridization (Ross \& Grant, 1985), have extremely similar polar lipid patterns. However, there are differences in the minor components, particularly between Natronococcus and Natronobacterium spp., and these differences have recently been emphasized (Morth \& Tindall, 1985).

Abbreviations: PG, phosphatidylglycerol; PGP, phosphatidylglycerophosphate; DEPT, distortionless enhancement by polarization transfer; FAB, fast atom bombardment. 
Despite the undoubted usefulness of polar lipid patterns in the taxonomy of the halophilic archaebacteria, very little detailed chemical characterization of these lipids has been carried out, identifications having been based largely on $R_{F}$ values and differential staining procedures. Indeed, the only detailed chemical work is that of Kates and coworkers (Kates, 1978, 1986), who characterized the complex lipids of three species that grow at neutral pH (Kates, 1978; Evans et al., 1980; Kushwaha et al., 1982).

We report here a detailed chemical characterization, based on ${ }^{13} \mathrm{C}$ NMR assignments, of the major polar lipids (PG and PGP) found in Natronobacterium and Natronococcus spp., together with the amounts of $\mathrm{C}_{20}, \mathrm{C}_{20}$ and $\mathrm{C}_{25}, \mathrm{C}_{20}$ forms of these polar lipids.

\section{METHODS}

Micro-organisms and culture conditions. Strains of Natronobacterium pharaonis (NCMB 2191), Nb. gregoryi (NCMB 2189), Nb. magadii (NCMB 2190), Natronococcus occultus (NCMB 2192) and Halobacterium cutirubrum (NCMB 763) were obtained from the National Collection of Marine Bacteria, Torry Research Station PO Box 31, Aberdeen AB9 8DG, UK, and were grown as described by Tindall et al. (1984). Cells were harvested in the late exponential phase by centrifugation, washed with a basal salt solution, and lyophilized.

Extraction and isolation of lipids. Lyophilized cells $(30 \mathrm{~g})$ were extracted continuously by Soxhlet for $12 \mathrm{~h}$, with $\mathrm{CHCl}_{3} / \mathrm{MeOH}(1: 1, \mathrm{v} / \mathrm{v})$ and then with $\mathrm{MeOH} / \mathrm{H}_{2} \mathrm{O}(1: 1, \mathrm{v} / \mathrm{v})$. The extracts were pooled and evaporated under vacuum. Total lipid extracts, dissolved in $20 \mathrm{ml} \mathrm{CHCl} / 3 / \mathrm{MeOH} / \mathrm{H}_{2} \mathrm{O}(65: 25: 4$, by vol. $)$, were mixed with $5 \mathrm{~g}$ silica gel (Kieselgel 70-230 mesh, Merck) and dried; the dry material was added to the top of silica gel columns ( $70 \mathrm{~g}$ Kieselgel 70-230 mesh, Merck) $(40 \mathrm{~cm} \times 10 \mathrm{~mm}$, i.d.). The columns were eluted with 31 of a step gradient of $0-$ $50 \%(\mathrm{v} / \mathrm{v}) \mathrm{MeOH}$ in $\mathrm{CHCl}_{3}$ in $5 \%$ increments ( $250 \mathrm{ml}$ for each gradient step). PGP was eluted with $\mathrm{CHCl}_{3} / \mathrm{MeOH}$ $(9: 1, v / v)$ and PG was eluted with $\mathrm{CHCl}_{3} / \mathrm{MeOH}(85: 15, \mathrm{v} / \mathrm{v})$. Both compounds were pure by TLC analysis (solvent system $\mathrm{CHCl}_{3} / \mathrm{MeOH} / \mathrm{H}_{2} \mathrm{O}, 65: 25: 4$, by vol.) and were weighed to evaluate their relative percentages.

Methanolysis of lipids. Acid methanolysis of lipids was done in dry methanolic $6 \mathrm{M}-\mathrm{HCl}$. The reaction mixtures were heated at $100^{\circ} \mathrm{C}$ in stoppered reaction tubes for $6 \mathrm{~h}$. After being cooled, the hydrolysis products were dried under vacuum and then treated with equal volumes of $\mathrm{CHCl}_{3}$ and $\mathrm{H}_{2} \mathrm{O}$. After thorough mixing, the two phases were analysed by HPLC, using a Waters Associates apparatus equipped with a differential refractometer. 2,3-Di$O$-phytanyl-sn-glycerol and 2-O-sesterterpanyl-3-O-phytanyl-sn-glycerol were detected in the chloroform phase by

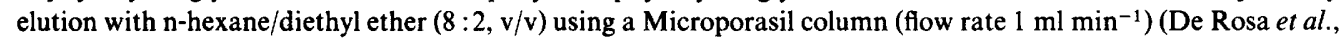
1982). Glycerol was identified in the aqueous phase by elution with acetonitrile $/ \mathrm{H}_{2} \mathrm{O}(9: 1, \mathrm{v} / \mathrm{v})$ on a carbohydrate column (flow rate $2 \mathrm{ml} \mathrm{min}^{-1}$ ).

$T L C$. This was done on $0.25 \mathrm{~mm}$ layers of silica gel F 254 (Merck), activated by heating at $100{ }^{\circ} \mathrm{C}$ for $2 \mathrm{~h}$. Solvents included $\mathrm{CHCl}_{3} / \mathrm{MeOH} / \mathrm{H}_{2} \mathrm{O}\left(65: 25: 4\right.$, by vol.) for PG and PGP; $\mathrm{CHCl}_{3} / \mathrm{MeOH}(7: 3, \mathrm{v} / \mathrm{v})$ for glycerol; and double development with $\mathrm{n}$-hexane/acetone $(95: 5, \mathrm{v} / \mathrm{v})$ and toluene/acetone $(97: 3, \mathrm{v} / \mathrm{v})$ (Ross et al., 1981) for 2,3-di- $O$-phytanyl-sn-glycerol and 2-O-sesterterpanyl-3- $O$-phytanyl-sn-glycerol.

Compounds were detected either by exposure to $\mathrm{I}_{2}$ vapour, or by spraying with $\mathrm{Ce}\left(\mathrm{SO}_{4}\right)_{2}$. Specific reagents included the Dittmer and Lester reagent (Dittmer \& Lester, 1964) for phospholipids and the periodate-Schiff reagent for vicinal glycols (Baddily et al., 1956).

Quantitative analysis. Phosphorus was determined by the method of Ames (1966) and glycerol was assayed enzymically (Wieland, 1965). Glycerol diethers were determined gravimetrically after drying to constant weight.

Isolation of water soluble low $M_{\mathrm{r}}$ compounds. Dried cells $(3 \mathrm{~g})$ were used for the extraction of intracellular components. Cells were diluted with distilled water and subsequently lysed by freeze-thawing. Compounds were isolated and purified as described by Galinski \& Trüper (1982) for ${ }^{13} \mathrm{C}$ NMR analyses.

${ }^{13} \mathrm{C} N M R$ spectroscopy. PG and PGP samples for NMR were prepared by dissolving each phospholipid in $0.5 \mathrm{ml} \mathrm{C} \mathrm{HCl}_{3} / \mathrm{C}^{2} \mathrm{H}_{3} \mathrm{O}^{2} \mathrm{H}(7: 3, \mathrm{v} / \mathrm{v})$.

For aqueous samples, obtained by lysis of cells, samples for ${ }^{13} \mathrm{C}$ NMR spectra were supplemented with ${ }^{2} \mathrm{H}_{2} \mathrm{O}$ $(0.2 \mathrm{ml})$ as an internal lock signal and an adequate amount of $\mathrm{C}^{2} \mathrm{H}_{3} \mathrm{O}^{2} \mathrm{H}$ as an internal standard (49.0 p.p.m. relative to tetramethylsilane).

All the ${ }^{13} \mathrm{C}$ NMR spectra were run at $125 \mathrm{MHz}$ on a Bruker WH-500 spectrometer. Chemical shifts are quoted in p.p.m. relative to tetramethylsilane. ${ }^{13} \mathrm{C}$ Fourier transform NMR spectra, with sweep widths and transmitter frequencies optimized for the lowest possible digital resolution ( $\mathrm{Hz}$ per data point), were obtained from $32 \mathrm{~K}$ free induction decay signals. Exponential multiplication for carbon NMR was applied previously by Fourier transformation; line broadening constants were adapted for the digital resolution.

Analysis of multiplicities for samples of PG and PGP was achieved by distortionless enhancement by the polarization transfer (DEPT) technique, using a commercially available microprogramme. Two DEPT experiments were performed using polarization transfer pulses of $90^{\circ}$ and $135^{\circ}$, respectively, obtaining in the first case only signals for methine groups and in the other case positive signals for methine and methyl groups, and negative signals for methylene groups. 
Mass spectrometry. MS analyses were done with a Kratos MS-50 instrument equipped with a Kratos fast atom bombardment (FAB) source. The positive FAB mass spectra were obtained by dissolving the samples in a glycerol matrix, adding $0 \cdot 1 \%$ sodium acetate in methanol to the probe prior to bombardment with Argon atoms of having a kinetic energy equivalent to $2-6 \mathrm{keV}$. The negative FAB mass spectra were obtained as described for the positive FAB, without the addition of sodium acetate.

IR spectra. These were recorded using a Perkin-Elmer 257 infrared spectrophotometer.

Optical rotation. Optical rotations were measured in $\mathrm{CHCl}_{3}$ using a Perkin-Elmer 141 polarimeter.

\section{RESULTS AND DISCUSSION}

\section{Lipid extraction}

The yield of lipid (\% of dried cells) was 6.8 for $N b$. pharaonis, $7 \cdot 0$ for $N b$. magadii, $9 \cdot 2$ for $N b$. gregoryi and $7 \cdot 2$ for Nc. occultus. Previous analyses of haloalkaliphiles have yielded similar quantities of lipids (De Rosa et al., 1982, 1983).

\section{Quantitative analyses}

On the basis of polarity, we expected PG to elute before PGP. However, PGP eluted before $\mathrm{PG}$ at $10 \% \mathrm{MeOH}$ in $\mathrm{CHCl}_{3}$, suggesting that complex formation had taken place. This aspect is discussed later. The $\mathrm{C}_{25}, \mathrm{C}_{20}$ and $\mathrm{C}_{20}, \mathrm{C}_{20}$ forms of each phospholipid eluted together.

PG and PGP together accounted for most of the polar lipids from all species examined, in accord with the data reported by Tindall et al. (1984) and Morth \& Tindall (1985); only trace amounts of one or two other unidentified phospholipids were present. The relative proportions of PG and PGP in the four species are shown in Table 1. It can be seen that PGP predominates in these organisms, comprising from $89.0 \%$ for $\mathrm{Nb}$. gregoryi to $74.0 \%$ for $\mathrm{Nc}$. occultus. These analyses (for PG and PGP respectively) compare with $70 \%$ and $4 \%$ in $\mathrm{H}$. cutirubrum, $62 \%$ and $11 \%$ in Halobacterium marismortui and $30 \%$ and $44 \%$ in Halobacterium mediterranei (R-4), where the remainder of the polar lipids are composed mainly of glycolipids (Kushwaha et al., 1982).

Acid methanolysis yielded glycerol, phosphate and diether in the molar ratio 1:1:1 for PG and $1: 2: 1$ for PGP. Glycerol and phosphate were quantified and identified as described in Methods; diethers were quantified and identified by comparison with authentic samples (De Rosa et al., 1982).

The proportions of the $\mathrm{C}_{25}, \mathrm{C}_{20}$ and $\mathrm{C}_{20}, \mathrm{C}_{20}$ forms of both PG and PGP were determined by HPLC after hydrolysis to release the core structures. The results are shown in Table 2 . The three

Table 1. Relative proportions of $P G$ and $P G P$ in haloalkaliphiles

The total amount of $P G$ plus $P G P=100$.

$\begin{array}{lcc}\text { Haloalkaliphile } & \text { PG } & \text { PGP } \\ \text { Nb. pharaonis } & 14 & 86 \\ \text { Nb. magadii } & 15 & 85 \\ \text { Nb. gregoryi } & 11 & 89 \\ \text { Nc. occultus } & 26 & 74\end{array}$

Table 2. Proportions of 2,3-di-O-phytanyl-sn-glycerol and 2-O-sesterterpanyl-3-O-phytanyl-snglycerol core lipids in haloalkaliphiles

The total amount of either PG or PGP $=100$.

Haloalkaliphile

Nb. pharaonis

Nb. gregoryi

Nb. magadii

Nc. occultus

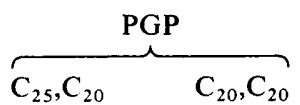

$90 \quad 10$

$55 \quad 45$

$60 \quad 40$

$35 \quad 65$ 


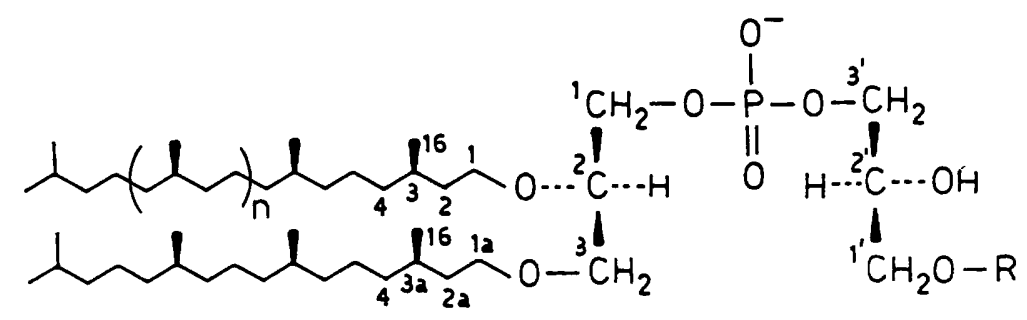

PG $P G P$<smiles>[R]C=CP(C)(=O)[O-]</smiles>

Fig. 1. Chemical structures of $\mathrm{C}_{20}, \mathrm{C}_{20}(\mathrm{n}=1)$ and $\mathrm{C}_{25}, \mathrm{C}_{20}(\mathrm{n}=2)$ phospholipids in haloalkaliphilic archaebacteria. $\mathrm{PG}=2,3$-di- $O$-phytanyl-sn-glycero-1-phosphoryl-3'-sn-glycerol. $\mathrm{PGP}=2,3$-di- $O$-phytanyl-sn-glycero-1-phosphoryl-3'-sn-glycero-1'-phosphate. $\mathrm{C}_{25}, \mathrm{C}_{20}$ forms have sesterterpanyl chains replacing phytanyl chains on $\mathrm{C}-2$ of the glycerol moiety.

Natronobacterium spp. showed a preponderance of the $\mathrm{C}_{25}, \mathrm{C}_{20}$ form for both $\mathrm{PG}$ and PGP, this being particularly marked for $\mathrm{Nb}$. pharaonis, whereas $N c$. occultus had a preponderance of the $\mathrm{C}_{20}, \mathrm{C}_{20}$ form for both PG and PGP. These results are comparable to those of Tindall (1985), although in that case, the proportions of $\mathrm{C}_{25}, \mathrm{C}_{20}$ had been determined on a total lipid extract. In contrast to the results of Tindall (1985), no $\mathrm{C}_{25}, \mathrm{C}_{25}$ forms were detected.

\section{Mass spectrometry}

Positive FAB mass spectra of PG showed $\mathrm{M}^{+}$at $m / z 828\left(\mathrm{M}+\mathrm{Na}^{+}\right)$for $\mathrm{C}_{20}, \mathrm{C}_{20}$ forms and at $898\left(\mathrm{M}+\mathrm{Na}^{+}\right)$for $\mathrm{C}_{25}, \mathrm{C}_{20}$ forms. Also present in the spectra were fragmentation peaks at $\mathrm{m} / \mathrm{z}$ 846 and $m / z 776\left(\mathrm{M}-\mathrm{CH}_{2} \mathrm{OH}\right)$ for $\mathrm{C}_{25}, \mathrm{C}_{20}$ forms and the $\mathrm{C}_{20}, \mathrm{C}_{20}$ forms, and $m / z 815$ and $m / z$ 745 for the loss of $\mathrm{CHOH}-\mathrm{CH}_{2} \mathrm{OH}$ from $\mathrm{M}^{+}$for $\mathrm{C}_{25}, \mathrm{C}_{20}$ and $\mathrm{C}_{20}, \mathrm{C}_{20}$ forms.

Additional diagnostic spectra were obtained by negative $\mathrm{FAB}$, which showed parent ions at $m / z 804(\mathrm{M}-\mathrm{H})^{-}$for $\mathrm{C}_{20}, \mathrm{C}_{20}$ forms and at $m / z 874(\mathrm{M}-\mathrm{H})^{-}$for $\mathrm{C}_{25}, \mathrm{C}_{20}$ forms.

Mass spectra of PGP showed the same peaks as PG due to the loss of the additional phosphate group.

All spectra showed a regular series of peaks relating to the sequential cleavage of saturated isopranoid units (De Rosa et al., 1982, 1983).

\section{IR spectroscopy}

The IR spectrum of PG in liquid films was comparable to that reported previously by Kates (1978) for $H$. cutirubrum, showing absorptions corresponding to hydroxyl groups $(-\mathrm{OH})$ at $3400 \mathrm{~cm}^{-1}$, ether $(\mathrm{C}-\mathrm{O}-\mathrm{C})$ at $1090 \mathrm{~cm}^{-1}$, phosphate $\mathrm{P}=\mathrm{O}$ and $\left.\mathrm{P}-\mathrm{O}-\mathrm{C}\right)$ at 1230 and $1050 \mathrm{~cm}^{-1}$ respectively, methine $(-\mathrm{C}-\mathrm{H})$ at $1350 \mathrm{~cm}^{-1}$, methyl $\left(-\mathrm{CH}_{3}\right)$ and methylene $\left(-\mathrm{CH}_{2}-\right.$ ) at 1465 and $2850-3000 \mathrm{~cm}^{-1}$. The spectrum of the PGP sample showed the same bands as PG but also additional bands for carbonyl $(\mathrm{C}=\mathrm{O})$ at $1680 \mathrm{~cm}^{-1}$ and a quaternary ammonium at 3000 and $1400 \mathrm{~cm}^{-1}$.

\section{${ }^{13}$ C NMR spectroscopy}

Table 3 indicates full ${ }^{13} \mathrm{C}$ NMR assignments for both PG and PGP. In the proton noise decoupled ${ }^{13} \mathrm{C}$ NMR spectrum of $\mathrm{PG}$, the 1 and $3^{\prime}$ carbons appeared as doublets with $J_{\mathrm{P}-\mathrm{O}-\mathrm{C}}=1 \mathrm{~Hz} .{ }^{13} \mathrm{C}$ NMR spectra of PG and PGP showed similar resonance except that in PGP 
Table 3. ${ }^{13}$ C NMR assignments for phospholipids $P G$ and $P G P$

${ }^{13} \mathrm{C}$ NMR spectra were recorded in $\mathrm{C}^{2} \mathrm{HCl}_{3} / \mathrm{C}^{2} \mathrm{H}_{3} \mathrm{O}^{2} \mathrm{H}(7: 3, \mathrm{v} / \mathrm{v})$ at $125 \mathrm{MHz}$; the chemical shifts are in p.p.m. with respect to tetramethylsilane. Chemical shift data on carbons 21-25 of the isopranoid unit in the $C_{25}$ chain were the same as carbons 16-20 in the $C_{20}$ chain. Multiplicities were obtained from DEPT experiments. s, Singlet; $d$, doublet; t, triplet; q, quartet.

$\begin{array}{lll}\text { Carbon atom* } & \text { PG } & \text { PGP } \\ 1 & 65 \cdot 9 \dagger \mathrm{t} & 65 \cdot 7 \dagger \\ 2 & 78 \cdot 4 \mathrm{~d} & 78 \cdot 3 \\ 3 & 71 \cdot 5 \mathrm{t} & 71 \cdot 2 \\ 1^{\prime} & 63 \cdot 4 \mathrm{t} & 66 \cdot 6 \dagger \ddagger \\ 2^{\prime} & 71 \cdot 9 \mathrm{~d} & 70 \cdot 3 \\ 3^{\prime} & 67 \cdot 2 \dagger \mathrm{t} & 66 \cdot 7 \dagger \ddagger \\ 1 & 69 \cdot 5 \mathrm{t} & 69 \cdot 4 \\ 1 \mathrm{a} & 70 \cdot 7 \mathrm{t} & 70 \cdot 7 \\ 2 & 37 \cdot 4 \mathrm{t} & 37 \cdot 3 \\ 2 \mathrm{a} & 37 \cdot 9 \mathrm{t} & 37 \cdot 8 \\ 3 & 30 \cdot 5 \mathrm{~d} & 30 \cdot 4 \\ 3 \mathrm{a} & 30 \cdot 7 \mathrm{~d} & 30 \cdot 6 \\ 4,6,8,10,12 & 38 \cdot 0 \mathrm{t} & 38 \cdot 0 \\ 5 & 25 \cdot 0 \mathrm{t} & 25 \cdot 0 \\ 7,11 & 33 \cdot 4 \mathrm{~d} & 33 \cdot 3 \\ 9 & 24 \cdot 9 \mathrm{t} & 24 \cdot 9 \\ 13 & 25 \cdot 2 \mathrm{t} & 25 \cdot 3 \\ 14 & 40 \cdot 0 \mathrm{t} & 39 \cdot 9 \\ 15 & 28 \cdot 5 \mathrm{~d} & 28 \cdot 5 \\ 16 & 20 \cdot 0 \mathrm{q} & 20 \cdot 1 \\ 17,18 & 20 \cdot 1 \mathrm{q} & 20 \cdot 2 \\ 19 & 23 \cdot 0 \mathrm{q} & 22 \cdot 9 \S \\ 20 & 23 \cdot 1 \mathrm{q} & 23 \cdot 0 \S \\ \text { I } & & 53 \cdot 4 \mathrm{q} \\ \text { II } & & 66 \cdot 8 \mathrm{t} \\ \text { III } & & 168 \cdot 9 \mathrm{~s}\end{array}$

* The carbon atom numbers refer to those given in Figs. 1 and 2.

$\dagger$ In the proton noise decoupled ${ }^{13} \mathrm{C}$ NMR spectrum signals are doublets with $J_{\mathrm{P}-\mathrm{O}-\mathrm{C}}=1 \mathrm{~Hz}$.

$\ddagger$ Assignments are interchangeable with one and other.

$\S$ Assignments are interchangeable with one and other.

due to the extra phosphate the $1^{\prime}$ carbon was shifted by $3 \cdot 2 \delta$ and appeared as a doublet with $J_{\text {P-O.C }}=1 \mathrm{~Hz}$ in the proton noise decoupled ${ }^{13} \mathrm{C}$ NMR spectrum. These results taken together with the analytical data and the MS and IR spectra establish the structures shown in Fig. 1. On the basis of the molecular rotation of PG, $[\alpha]_{D}=+28^{\circ}$, we believe that the chirality of both glycerols in the molecule is identical to that found in other extremely halophilic archaebacteria (Kates, 1978).

Although the structures of the $\mathrm{C}_{20}, \mathrm{C}_{20}$ forms of PG and PGP from the halobacterium $H$. cutirubrum were established by the classic work of Kates (1978), this work was based on laborious chemical procedures. This is the first determination of such structures by spectroscopic methods. Such methods are a simple but powerful adjunct to the conventional chemical procedures for the detailed structural analysis of such compounds.

During the course of the ${ }^{13} \mathrm{C}$ NMR analysis of PGP, signals distinct from those characteristic of PGP were observed. These signals $(\delta 53 \cdot 4,66 \cdot 8,168 \cdot 9)$ (Table 3$)$ are characteristic of glycine betaine (trimethylglycine) (Galinski \& Trüper, 1982). The inversion of PG and PGP (from all four species) on elution from silica columns is probably due to complex formation between PGP and glycine betaine (Fig. 2), resulting in a change in the polarity of the molecule. This complex is dissociated in solvents such as $\mathrm{CHCl}_{3} / \mathrm{MeOH} / \mathrm{H}_{2} \mathrm{O}(65: 25: 4$, by vol.), where PGP eluted from columns has the expected mobility. It is not clear whether PGP and glycine betaine are complexed within the cells and extract in this form in $\mathrm{CHCl}_{3} / \mathrm{MeOH}(1: 1, \mathrm{v} / \mathrm{v})$, or whether the extraction procedure itself results in the formation of the complex; since glycine betaine is a strong base and likely to form salt complexes, the latter is more likely. It is noteworthy that 
<smiles></smiles>

Fig. 2. Proposed complex formed between the phosphate group of PGP and the quaternary nitrogen of glycine betaine. $\mathrm{X}=2,3$-di- $O$-phytanyl-sn-glycero-1-phosphoryl-3'-sn-glycerol or 2-O-sesterterpanyl,3$O$-phytanyl-sn-glycero-1-phosphoryl-3'-sn-glycerol.

signals characteristic of glycine betaine were also found in the aqueous extracts of cells from all four species.

Glycine betaine is accumulated by many eubacteria as an osmoticum (Imhoff, 1986; Reed et al., 1986). This is the first evidence for the presence of this compound in an archaebacterium. Halophilic archaebacteria are unusual in that it is believed that osmotic protection is achieved by the accumulation of $\mathrm{K}^{+}$(Kushner, 1978; Bayley \& Morton, 1978) and to date, there is no evidence for the accumulation of any organic osmoticum (Tindall \& Trüper, 1986). However, it is doubtful if detailed spectrophotometric analyses have ever been made. We have also found glycine betaine in $H$. cutirubrum (NCMB 763). In order to establish if glycine betaine plays a role in osmotic protection in halobacteria it would be necessary to quantify this compound under different growth conditions. We are presently addressing this question.

We thank Mr E. Pagnotta, Mrs V. Calandrelli and Mr G. Pinch for their technical assistance, and Mr E. Esposito and Dr A. Trincone for their skilled assistance in some of the experiments. We also thank Mr R. Turco for the art work.

\section{REFERENCES}

Ames, B. N. (1966). Assay of inorganic phosphate, total phosphate and phosphatases. Methods in Enzymo$\log y 8,115-118$.

Baddily, J., Buchanan, J. G., Handschumacher, R. E. \& PresCotT, J. F. (1956). Chemical studies on the biosynthesis of purine nucleotides. Part I. The preparation of $N$-glycyl-glycosylamines. Journal of the Chemical Society, 2818-2823.

BAyLeY, S. T. \& MoRTON, A. (1978). Recent developments in the molecular biology of extremely halophilic archaebacteria. CRC Critical Reviews in Microbiology 6, 151-205.

De Rosa, M., Gambacorta, A., Nicolaus, B., Grant, W. D. \& Bu'Lock, J. D. (1982). An asymmetric diether lipid from alkaliphilic halophiles. Journal of General Microbiology 128, 343-348.

De Rosa, M., Gambacorta, A., Nicolaus, B. \& GRANT, W. D. (1983). A $C_{25}, C_{25}$ diether core lipid from archaebacterial haloalkaliphiles. Journal of General Microbiology 129, 2333-2337.

De Rosa, M. \& Gambacorta, A. (1986). Lipid biogenesis in archaebacteria. Systematic and Applied Microbiology 7, 278-285.

DitTMER, J. C. \& Lester, E. L. (1964). A simple, specific spray for the detection of phospholipids on thin layer chromatograms. Journal of Lipid Research 5, 126-127.
Evans, R. W., Kushwaha, S. C. \& Kates, M. (1980). The lipids of Halobacterium marismortui an extremely halophilic bacterium in the Dead Sea. Biochimica et biophysica acta 619, 533-544.

Galinski, E. A. \& TrüPER, H. G. (1982). Betaine, a compatible solute of the extremely halophilic phototrophic bacterium Ectothiorhodospiora halochloris. FEMS Microbiology Letters 13, 57-66.

IMHOFF, J. F. (1986). Osmoregulation and compatible solutes in eubacteria. FEMS Microbiology Reviews 39, 57-66.

KATES, M. (1978). The phytanyl ether-linked polar lipids and isoprenoid neutral lipids of extremely halophilic bacteria. Progress in the Chemistry of Fats and other Lipids 15, 301-342.

KATES, M. (1986). Influence of salt concentration on membrane lipids of halophilic bacteria. FEMS Microbiology Reviews 39, 95-101.

KUSHNER, D. J. (1978). Life in high salt and solute concentrations: halophilic bacteria. In Microbial Life in Extreme Environments, pp. 318-368. Edited by D. J. Kushner. London: Academic Press.

Kushwaha, S. C., Kates, M., Juez, G., RodriguezValera, F. \& Kushner, D. J. (1982). Polar lipids of an extremely halophilic bacterial strain (R-4) isolated from salt ponds in Spain. Biochimica et biophysica acta 711, 19-25. 
LANGWORTHY, T. A. (1985). Lipids of archaebacteria. In The Bacteria, vol.VIII, pp. 459-498. Edited by C. R. Woese \& R.S. Wolfe. London: Academic Press.

LANGWorthy, T. A. \& Pond, J. L. (1986). Archaebacterial ether lipids and chemotaxonomy. Systematic and Applied Microbiology 7, 253-257.

MORTH, S. \& TINDALL, B. J. (1985). Variation of polar lipid composition within haloalkaliphilic archaebacteria. Systematic and Applied Microbiology 6, 247250.

ReEd, R. H., BorowitzKa, L. J., Mackay, M. A., CHUDEK, J. A., Foster, R., WARR, S. C. R., MOORE, D. J. \& STEWART, W. D. P. (1986). Organic solute accumulation in osmotically-stressed cyanobacteria. FEMS Microbiology Reviews 39, 51-56.

Ross, H. N. M., Collins, M. D., Tindall, B. J. \& Grant, W. D. (1981). A rapid procedure for the detection of archaebacterial lipids in halophilic bacteria. Journal of General Microbiology 123, 75-80.

Ross, H. N. M. \& GRaNT, W. D. (1985). Nucleic acid studies on halophilic archaebacteria. Journal of General Microbiology 131, 165-173.

Ross, H. N. M., Grant, W. D. \& Harris, J. E. (1985). Lipids in archaebacterial taxonomy. In Chemical
Methods in Systematics, pp. 289-300. Edited by M. Goodfellow \& D. Minnikin. London \& New York: Academic Press.

TINDALL, B. J. (1985). Qualitative and quantitative distribution of diether lipids in haloalkaliphilic archaebacteria. Systematic and Applied Microbiology 6, 243-246.

TINDALl, B. J. \& TrüPER, H. G. (1986). Ecophysiology of the aerobic halophilic archaebacteria. Systematic and Applied Microbiology 7, 202-212.

Tindall, B. J., Ross, H. N. M. \& Grant, W. D. (1984). Natronobacterium gen. nov. and Natronococcus, gen. nov., two new genera of haloalkaliphilic archaebacteria. Systematic and Applied Microbiology 5, 41-57.

TorreblanCa, M., Rodriguez-Valera, F., Juez, G., Ventosa, A., Kamekura, M. \& Kates, M. (1986). Classification of non-alkaliphilic archaebacteria based on numerical taxonomy and polar lipid composition and description of Haloarcula gen. nov. and Haloferax gen. nov. Systematic and Applied Microbiology 8, 89-99.

Wieland, O. (1965). In Methods of Enzymatic Analysis pp. 211-214. Edited by H. U. Bergmeyer. New York: Academic Press. 